\title{
The Combination and Implementation of Enterprise Education and Vocational Education in Higher Vocational Logistics Management Specialty
}

\author{
Liang Kang* \\ Chongqing College of Electronic Engineering \\ Chongqing, China \\ richard12@163.com
}

\author{
Yong Ye \\ Chongqing College of Electronic Engineering \\ Chongqing, China \\ 41137405@qq.com
}

\begin{abstract}
In the development and reform of Higher Vocational Education in our country, enterprise education is deeply attached to the higher vocational colleges. It is a breakthrough for many professional reform experts to explore the path of integration the innovative education and vocational education actively; there is no exception for Logistics Management. This study is based on the current situation of the development of logistics industry and the demand for entrepreneurial talent, which analyses the necessity to combine the Logistics Management entrepreneurship education with vocational education, and puts forward the countermeasures.
\end{abstract}

Keywords-logistics management; enterprise education; vocational education; integration; necessity; countermeasures

\section{INTRODUCTION}

In recent years, the logistics industry has been rising rapidly under the impetus of China's economic development. The logistics industry is booming, and the demand for logistics talents is increasing, so the logistics management major has become a hot major. But with the advent of the era of knowledge economy, entrepreneurship and entrepreneurship education have become a new trend of the higher vocational education development reform in China, and the quantity and quality of the professional talent cultivation of logistics management are still unable to meet the needs of the development of logistics industry. It is a problem for logistics management major to think rationally and explore actively how to construct entrepreneurship education in combination with professional education and build the entrepreneurship education mode that integrates entrepreneurship education into professional education.

\section{THE DEVELOPMENT OF LOGISTICS INDUSTRY AND THE DEMAND ACTUALITY OF ENTREPRENEURIAL TALENTS}

Compared with the continuous rapid development trend of China's economy, the development of logistics industry lags behind the economic development, which has already had the restriction effect on the further rapid development of China's economy. In the economic development of China, the logistics industry has become an important industry to promote its development, which is also a new economic growth point for China's economic development and an important driving force for the development of the national economy. After entering 2015, Ali research center forecast that for this year's revenue, e-commerce service industry will be more than 1 trillion, and at the same time 13 trillion of e-commerce transaction scale will also be supported by e-commerce service industry. The development of modern logistics industry has an inseparable connection with e-commerce. Logistics is the basis of ecommerce, and e-commerce promotes the development of modern logistics industry in a faster way. The popularity of the Internet has promoted the rapid development of e-commerce, and under the background, the logistics development mode has been unable to meet the development of e-commerce. Logistics development mode innovation has become the current trend of logistics development, while innovative logistics requires more high-quality logistics talents with entrepreneurial and innovative consciousness and professional practical ability.

In the logistics industry, there are mainly two kinds of logistics talents, one for logistics operation and the other for logistics management. From the point of the current incomplete statistics, China has opened more than 1,600 colleges, secondary technical schools, secondary and senior vocational schools setting up logistics major with the logistics operational talents as their main cultivating object. The demand for operational talents in the logistics industry is reaching saturation point. However, it is increasingly difficult for logistics manage talents to meet the increasing demand of foreign enterprises, joint ventures and domestic top 500 enterprises in recent years. In particular, the demand for senior logistics talents has a serious fault, there is a great lack of talents in logistics research, planning, etc.. The key to logistics development lies in talent, which has been already practiced by the developed countries. As a compound service industry, modern logistics industry has strong comprehensiveness and a great demand for innovative, entrepreneurial, ability-oriented integrated management and technical talents. The proportion of graduates' entrepreneurship in higher vocational colleges was 2.9 \%, 3.3 \%and $3.8 \%$ respectively in 2012, 2013 and 2014. Although it has been on the rise in recent years, it is obvious that the proportion of innovation and entrepreneurship among logistics major is low compared with other majors. In the face of this demand, the school must strive to cultivate innovative and entrepreneurial logistics talents. Therefore, it is necessary to actively explore the integration of entrepreneurship

${ }^{*}$ Corresponding author: Liang Kang. 
education with professional education in logistics management major [1-2].

\section{THE NECESSITY OF THE INTEGRATION OF ENTREPRENEURSHIP EDUCATION AND PROFESSIONAL EDUCATION IN LOGISTICS MANAGEMENT MAJOR}

Entrepreneurship education is the cultivation for pioneering talents. In many developed countries, higher vocational colleges generally focus on entrepreneurship education and cultivating students' entrepreneurship ability. As the new concept of higher vocational education, entrepreneurship education doesn't simply refer to a kind of education mode, but is consistent with professional education goal, taking the cultivation of high quality talents with innovative spirit and practice ability as the main task. From this point of view, there are a lot of intersections between the entrepreneurship education and professional education in higher vocational education, which interact on each other and supplement each other.

First of all, entrepreneurship education takes professional education as the starting point, and professional education is the basis of entrepreneurship education. It is not practical for entrepreneurship education of logistics management major to break away from the starting point and basis, professional education. A variety of practices showed that, the majority of college students' entrepreneurship activities are closely associated with their own majors. It is the entrepreneurial tendencies of vast majority of college students to find business opportunities in their familiar field and carry out entrepreneurship practice.

Secondly, in logistics management major, entrepreneurship education can promote the deepening of professional education. The implementation of entrepreneurship education makes a new requirement for the reform of professional education of logistics management major. In the logistics management professional education, the penetration and integration of entrepreneurship education concept are the requirements to improve and deepen the logistics management professional education. Highlighting practicality and practical ability is the current reform direction of professional education of logistics management major. This reform aims to promote school education of logistics management major to seamlessly joint the enterprise production practice. And entrepreneurship education of logistics management major has provided a clearer direction to the logistics management professional education for the cultivation of students' innovative spirit and entrepreneurial quality.

Thirdly, the talents cultivated by entrepreneurship education of logistics management major need to have not only a higher psychological quality, but also more complete knowledge structure and strong practical ability, etc., while pure entrepreneurship education or professional education is not able to fully complete the cultivation of student's qualities. Only by combining the entrepreneurship education with professional education in logistics management major, can we develop the logistics management professional talents needed by the society and meet the reform trend of logistics management.

\section{IMPLEMENT SUGGESTIONS FOR THE INTEGRATION OF ENTREPRENEURSHIP EDUCATION AND PROFESSIONAL EDUCATION IN LOGISTICS MANAGEMENT MAJOR}

2015 Chinese university student employment report released by Ministry of Education showed that the proportion of entrepreneurial graduates of the year 2014 from the higher vocational colleges in China was 3.8\%, while the proportion of that was $20 \%$ to $30 \%$ in the western developed countries. It can be seen from the comparison that there is still a long way to go for the entrepreneurship education in higher vocational colleges in China. Currently, professional education of logistics management has been unable to meet requirements of social development. How to combine entrepreneurship education with professional education is the top priority of professional education in logistics management major. In general, professional education of logistics management can start from professional basic courses, professional theory courses and professional practice links to explore the integration of entrepreneurship education and professional education.

A. Integrate the relevant entrepreneurship knowledge into the basic course teaching of logistics management major

Basic courses of logistics management major, from the narrow sense, usually only include public basic courses, such as English, computer, mathematics, political legal basis and so on, which have to be learned. As general basic courses, public basic courses play an important role on college students' basic education quality construction, and are helpful for students to adapt to the basic entrepreneurship work better after entering society. Basic foreign language and computer knowledge is the essential condition for college students to start their own business in any industry. Besides, it also requires certain written application ability, measurement ability, political and legal culture.

In addition to the public basic courses, logistics management major can also set up general economic and technical courses, as well as the platform course of business administration major. Logistics management major belongs to business administration major. General economic and technical courses not only provide the liberal education in the economic field for logistics management students, but also help the logistics management students to be consciously converted into the role of social, economic and legal person as soon as possible, so as to provide certain entrepreneurial consciousness and economic and legal cultivation for the future entrepreneurship of logistics management students. And the technical courses, including engineering graphics and mechanical engineering, can provide the certain knowledge structure for the future professional learning of logistics equipment and logistics operation in logistics management major, to lay a more solid foundation for the entrepreneurship. Although from a professional point of view, the platform course of business administration major is not related to the logistics management major, in entrepreneurship, business administration, and marketing and financial management are essential knowledge to be mastered. These courses added in the basic courses of logistics management major, will be conducive to the construction of a relatively complete entrepreneurial talent knowledge system, effective to provide management, 
finance, planning, information and other three-dimensional thinking for the future entrepreneurship of logistics management students. Integrating these professional basic courses into the basic courses of logistics management major, in the long term, is to provide a basic channel for the cultivation of students' entrepreneurial consciousness and provide the most basic knowledge reserve to the future entrepreneurship of logistics management students [3-5].

\section{B. Integrate the entrepreneurship education system into the professional education system of logistics management major}

Theory courses of logistics management major can be divided into two categories. One is the professional basic course of logistics management major, and the other is the logistics management specialized course. In the logistics management professional education, the integration of entrepreneurship education system into its professional education system should be strengthened in its professional curriculum system integration into the enterprise education system. Logistics and supply chain management are major professional basic courses for application-oriented logistics management major, which is an introductory course for the following more specialized courses. In professional basic course reform, it is necessary to integrate the entrepreneurial talent cultivation into it, change the students' learning content and focus according to the course changes, and focus on the teaching of logistics entrepreneurship knowledge. At the same time, the assessment method should be optimized accordingly. The assessment can include logistics business that is suitable for individual entrepreneurship and is related to small logistic enterprise survey and starting a logistic enterprise, such as express business, highway break bulk, etc.. In the learning of these courses, the latest trend of logistics development and the organizational form of logistics enterprises are all important points to be mastered in the basic courses of logistics management major, to provide a relatively broad professional perspective for students, arouse students' future entrepreneurial consciousness in the field of logistics, and lead students to think more about entrepreneurship. The cohesion and intersection problem of professional basic course and specialized course is the focus of the whole logistics management professional course reform, and professional basic course students should free up the class hours for professional introduction knowledge accumulation required by the students' entrepreneurship in the field of logistics management major.

Specialized course is the professional theory course of logistics management major, which is the most important course group of logistics management major. Logistics objective relationship management, third-party logistics, logistics cost, procurement and storage, distribution, transportation management, etc., are specialized courses of logistics management major. Based on the statistics of college students' entrepreneurial practice in the world, the proportion of entrepreneurship that starts on the basis of their own majors is the highest among college students. The first choice for college students' entrepreneurship is the industry they know and are familiar with. Even if they do not start a business based on their major, many of their professional knowledge will be applied to the operation of the enterprise. Professional knowledge precipitation is of great significance to entrepreneurship education. So, in various kinds of course teaching of professional education, the cultivation of entrepreneurial knowledge should be consciously blended in among them, in order to provide more clear goals and the steady impetus for the practical courses learning in the future.

In the process of the teaching specialized courses, the teaching content, in addition to including the professional cultivation plan and teaching outline requirements, should also include knowledge that may occur during the process of entrepreneurship, and teach the solutions of some entrepreneurship problems.

For example, the estimation method of different goods loading quantity can be added to the distribution or transportation course of logistics management major, so as to enable students to master how to optimize and choose the path of regional distribution within the province and the distribution within the city. In the teaching of logistics customer management course, it is important to maintain the operation mode of the relationship between upstream and downstream customers in small logistics enterprises. The entrepreneurship education idea should be integrated into professional teacher's education concept, which can promote the full play of entrepreneurship education's subjective initiative in logistics management major and combine entrepreneurship education with professional education in logistics management professional courses.

\section{Integrate the entrepreneurship education practice activities into the practice project of logistics management major}

It is the general goal of education of higher vocational colleges to cultivate students' innovative and entrepreneurial ability. However, the cultivation of this ability is not simply based on theory course teaching, also needs to be co-cultivated by practice teaching, especially for the logistics management major. The logistics management major should integrate the entrepreneurship education practical activities organically into the professional education practice project according to the practice course layout system. There are three kinds of common practical projects of logistics management major: the first is the lecture and visit, the second is simulation and competition, and the third is internship and practical operation. The lecture and visit are the practice activities that students of the logistics management major are connected more after entering the school. Schools generally invites social successful people to do report, or lead the students to visit the production, circulation enterprises related to logistics management, in order to make students know the logistics industry through the intuitive feelings. In this part, the school can also invite the typical characters with successful entrepreneurial experience. These people can be famous people, or graduates who have just made some achievements in their business. Through their introduction to their own entrepreneurial experience, they can stimulate students' interest in entrepreneurship and provide students with relative experience for the future entrepreneurship [6-7].

During the visit of enterprise practice, the school may invite relevant enterprise personnel to tell the history of the entrepreneurship and development of the enterprise, to 
cultivate students to form an intuitive entrepreneurship consciousness, and to know more about the corporate operation activities and production methods related to logistics management major. However, the content arrangement of various lectures and visit should also be based on the students' reality, to focus on view of life, value, entrepreneurial passion and so on in face of the junior students, to focus on more professional entrepreneurship knowledge and project selection in face of the junior students [8].

It is also a common practice teaching method in logistics management major to simulate the actual operation of the enterprise. In the process of simulation of enterprise operation, students can make assumptions about their positions through a certain division of labor, and improve the operation effect of the company through a series of professional efforts. The process has actually been similar to the future entrepreneurship. The students can choose the leader or the author to simulate, and have a preliminary feeling for the risks the enterprises face, so as to promote the improvement of students' entrepreneurial ability. In the logistics management professional education, various entrepreneurship competitions can be added, to exercise students' entrepreneurial consciousness and entrepreneurial skills. In addition, the entrepreneurship education can be properly integrated into the logistics management major in internship and practical operation projects. Generally speaking, the relatively complicated internship position can foster students' entrepreneurial ability more, and the students who are good at thinking are have better entrepreneurship education effect. At the stage of actual operation, teachers and schools should actively support students' entrepreneurial ideas, such as helping to coordinate students' entrepreneurship time and class time, solving students' problems in entrepreneurship, etc., so that students' entrepreneurship and professional education can be deeply combined through practical projects.

\section{CONCLUSIONS}

In the current professional teaching reform of logistics management, as a new acting point, entrepreneurship education is the task that logistics management major must meet. The logistics management major should, based on the correct understanding of its development needs, determine the necessity of combining entrepreneurship education with professional education, and actively explore the methods to combine entrepreneurship education with professional education.

\section{ACKNOWLEDGMENT}

The research is supported by higher education research reform project of CQ (162070).

\section{REFERENCES}

[1] Zhao Y. Who's Afraid of the Big Bad Dragon: Why China Has the Best (and Worst) Education System in the World [M]. 2014. vol. 2. pp.68-73.

[2] Boulos A. Conceptualisation of constraints on creativity in teaching in higher education: Towards the possibility of challenging practices in an Irish university[D] , 2013

[3] Lee M H. A tale of two cities: Comparing higher education policies and reforms in Hong Kong and Singapore[J]. Australian Journal of Education, 2002, 46(3): 255-286.

[4] Achieving quality learning in higher education[M]. Routledge, 2012.

[5] Drucker P. Innovation and entrepreneurship [M]. Routledge, 2014

[6] Laukkanen M. Exploring alternative approaches in high-level entrepreneurship education: creating micromechanisms for endogenous regional growth [J]. Entrepreneurship \& Regional Development, 2000, 12(1): 25-47.

[7] Powell J J W, Bernhard N, Graf L. The emergent European model in skill formation comparing higher education and vocational training in the Bologna and Copenhagen processes [J].Sociology of Education, 2012, 85(3): 240-258

[8] Boyd D. Why youth (heart) social network sites: The role of networked publics in teenage social life[J]. MacArthur foundation series on digital learning-Youth, identity, and digital media volume, 2007: 119-142. 